\title{
EDITORIAL
}

\section{De la noción de reproducción a la dimensión de procreación}

Muy honrosamente, La Revista de la Sociedad Colombiana de Obstetricia y Ginecología me ha solicitado colaborar con el editorial de esta entrega.

Brújula invaluablè de consulta para quienes desde sus respectivas realidades la requieren, esta publicación representa un permanente y claro aporte en la perspectiva permanente de dilucidar la duda, y abrir la mirada a nuevos horizontes con información clínica clara y precisa, tanto como con ininterrumpidas reflexiones impresas de sentido humanista solidario, equitativo y cálido.

Ha sido la nobilísima empresa humana y científica adelantada desde estas páginas, hospederas incansables de ilustración y sensibilidad, el cultivar la cultura del más profundo respeto por los derechos y las necesidades de la mujer en su condición de género, frecuentemente bien distantes cuando no divergentes y hasta en contravía de crudas realidades históricas y sociales determinantes de opresión, segregación y discriminación de la mujer, precisamente por su condición de tal.

Intensificadas todas ellas en la mujer gestante, para repercutir entonces en la prole, en recurrencia inaceptable, cuando ello ocurre cada vez.

Lograr la sociedad que para la mujer permita asumir la procreación como realización y como logro, enaltece, ennoblece y dignifica la condición humana, la condición del género humano, y la condición del género mujer.

$Y$ de suyo y por ende, la de la progenie.

La de la prole.

Y la de la especie, cuando para continuar siendo vuelve a ser, cada vez que está naciendo un nuevo ser.

Más allá de la ilustración clínica, tecnológica o procedimental, en estas páginas se consulta y entrega un solidario expediente de respaldo a la tan inmensamente estimable "sui generis" femenina condición, realizada, cuando gestante, en su máxima expresión de potencial procreador.

Mucho mas allá de la noción simple y simplista de reproducción, la dimensión de procreación, enaltece la gestación y la gestante.

El ampliamente utilizado término de "reproducción" aplicado a los procesos humanos, incorpora elementos francamente depreciativos, disminuyentes y minusvalorantes de la individualidad del nuevo ser.

Porque reproducción se aplica a la réplica de un original: una litografía, un facsímil, o un clone.

Réplicas disminuidas de lo que constituyera su original primero.

Réplicas minusvaliosas y minusvaloradas.

Generación tras generación, la noción de reproducción aplica depreciaciones, disminuciones y minusvaloraciones sucesivas, afectando a nuestra prole, a nuestra progenie.

En cada ocasión y en cada ser, única e individual. 
Poseedora de insustituible identidad.

Generación y génesis del género, del género humano, conjunto mayor de las identidades diferentes.

Identidades cada vez únicas, y nuevas cada vez.

Trascendente en el pretérito de los momentos de la concepción, y trascendente en el futuro de los del nacimiento, la procreación humana, fruto y simiente del género, proyecta su presencia cósmica en ininterrumpida sucesión de nuevos seres, siendo cada quien como en efecto es, en convivencia con su diferente similar.

Para cuya reflexión sensible, hemos abordado esperanzados la nave de estas páginas propicias para la visión humanista, equitativa y solidaria de la atención en salud femenina, materna y perinatal.

SANTIAGO CURREA GUERRERO

Director General. Instituto Materno Infantil Concepción Villaveces de Acosta. Regencia Académica. Universidad Nacional de Colombia. 